\title{
Impact of Lactic Acid Bacteria on Dairy Animal's Performance
}

\author{
Murad HA and Azzaz HH* \\ Department of Dairy Sciences, National Research Centre, Egypt
}

Submission: May 06, 2019; Published: May 29, 2019

*Corresponding author: Azzaz HH, Department of Dairy Sciences, National Research Centre, 33 Buhouth St, Dokki, Giza, Egypt

\begin{abstract}
Growing of public concerns towards use of antibiotics in animal feeding paved the way for probiotics utilization enlargement. Lactic acid bacteria (LAB) as a probiotic could improve dairy animal's performance through prevention of ruminal acidosis; stimulate digestive enzymes production and secretion and stimulate animal's immune system. The actions of LAB are species and strain specific and depend on their availability and viability in the host animal gastrointestinal tract. Therefore, the current review focus on impact of LAB on dairy animal's feed intake, ruminal fermentation, nutrients digestibility, blood metabolites, milk yield and milk composition.
\end{abstract}

Keywords: Probiotics; Lactic acid bacteria; Dairy animals; Feed; Blood; Milk production

Abbreviations: GIT: Gastrointestinal Tract; LAB: Lactic Acid Bacteria; DMI: Dry Matter Intake; NDF: Neutral Detergent Fiber; NEFA: NonEsterifies Fatty Acids; SCC: Somatic Cell Count

\section{Introduction}

Improve dairy animal's health and its productive performance has always remained a primary goal of researchers associated with the dairy animal production. This goal could be achieved by making desirable manipulation of rumen fermentation through using probiotics. Probiotics are live microbes beneficially affects the host animal by improving microbial balance of its gastrointestinal tract [1]. Probiotics are broad and may include fungi, bacteria and yeast cells. Most of bacterial probiotics preparations are containing lactic acid bacteria (LAB) like Lactobacillus acidophilus, Lactobacillus plantarum, Streptococcus bovis, Streptococcus faecium, Enterococcus faecium and Enterococcus faecalis [2]. Lactic acid bacteria (LAB) are gram-positive, acid-tolerant, either rod-shaped (bacilli) or spherical (cocci) bacteria. These bacteria are naturally found in the gastrointestinal tract (GIT) of the ruminants, produce lactic acid as the major metabolic end product of carbohydrate fermentation. The positive effects of LAB on dairy animal's performance have been reported [1-3], but the actions of LAB are species and strain specific and depend on their availability and viability in the host animal GIT. There are many mechanisms have been proposed to explain LAB positive effects including: A) antagonist the harmful bacteria in GIT through production of lactic acid and bacteriocins [4]; B) compete with pathogens for adhesion and nutrients sites [2]; C) stimulate animal's immune response through activate phagocytosis and natural killer cells [5]; D) detoxification of GIT toxins [6] and E) stimulate digestive enzymes production and secretion [7].
However, LAB might help for prevention of ruminal acidosis, by allowing the ruminal microflora to adapt to the presence of lactate in the rumen [2]. As the energy issue is so critical for dairy animals in early lactation, LAB inclusion could promote nutrients uptake through decrease the thickness of the inflamed intestinal wall, as well as improve feed efficiency by diminish the amount of energy used for GIT tissue turnover [8]. There is an enlargement in utilization of probiotics (e.g. LAB) as a feed additive has been noticed. This may be due to grow of public concerns towards use of antibiotics in animal feeding [2]. The EU already bans use of antibiotics as animal's growth promoters in 2003 to avoid their harmful effects on both animal's and human immune system [9]. It is worth to mention that the volume of probiotic market reached $\$ 33.19$ billion in 2015 and expected to reach $\$ 46.55$ billion in 2020 which reflecting the importance of the probiotics. Therefore, the current review will focus on the impact of LAB as a main bacterial probiotic on the dairy animal's performance

Lactic Acid Bacteria Impact on Feed intake and Feed Efficiency

In general supplementing dairy animals with LAB has been shown to improve feed efficiency with little change in dry matter intake (DMI) [10]. In this concern, cows fed mixture of L. acidophilus, $L$. casei, E. faecium and mannanoligosaccharide consumed $0.42 \mathrm{~kg} / \mathrm{d}$ less DM and produced $0.73 \mathrm{~kg} / \mathrm{d}$ more milk [11]. Moreover, feeding dairy cattle combination of L. acidophilus 
(LA747), L. acidophilus strains (LA45) and P. freudenreichii (PF24) had no effect on DMI [12]. Also, no effect was detected for Lactobacillus acidophilus $\left(10^{9} \mathrm{CFU} / \mathrm{g}\right)$ supplementation on DMI by lactating Holstein cows [13].

\section{Lactic Acid Bacteria Impact on Ruminal Fermentation}

It has been reported that supplemented dairy cows with LAB (Bacillus subtilis natto) lead to increase ruminal total VFA concentrations especially propionate $[14,15]$. Since propionate is the precursor for gluconeogenesis and increase its concentration in the rumen mean more glucose availability. In contrast, Holstein cows treated with $L$. acidophilus and $P$. freudenreichii did not show any change on their ruminal total VFA's and ammonia concentrations [12-13].

\section{Lactic acid Bacteria Impact on Nutrients Digestibility}

In general, lactic acid bacteria inclusion in ruminant's diets has led to improve nutrients digestibility. In this concern, cows supplemented with $B$. licheniformis showed significant differences in OM, CP, NDF and ADF digestibility coefficients [16]. Also, apparent total tract digestibilities of DM, OM, CP, CF and NFE for goats fed lactobacillus acidophilus showed significant improvement compared with those of the control [3]. In contrast, neutral detergent fiber (NDF), protein or starch digestibility not change due to addition of LAB to animals' diets [12].

\section{Lactic acid Bacteria Impact on Blood Metabolites}

lactating dairy cows suffering a negative energy balance during early lactation because the energy output in milk is greater than energy intake from feed; therefore, cows mobilize fat reserves to meet their energy requirements and this led to marked change in their blood metabolites. Positive effect of LAB (Enterococcus faecium) on availability of energy for postpartum cows has been reported [17]. The treated cows showed higher blood glucose and insulin concentrations [17]. In addition, it has been noticed that cows supplemented with Bacillus subtilis natto showed low concentration of blood non-esterifies fatty acids (NEFA) which indicates that cows are mobilizing less energy from adipose deposits to meet their energy requirements [14]. Less subclinical ketosis has been observed after calving in cows consuming Bacillus pumilus in their diets [18]. These reports show that LAB has potential to make the diet more energetically favorable for cows during the transition period.

\section{Lactic acid Bacteria Impact on Dairy Animal's Milk Yield and Milk Composition}

Commonly, LAB inclusions in dairy animal's diets lead to increase milk yield with little effect on milk composition. Several studies on dairy animals fed combination of L. acidophilus. $L$. plantarum, L. casei and S.faecium concluded that animal's milk yield increased by 0.75 to $2.0(\mathrm{~kg} / \mathrm{d})$ [10]. Cow's milk yield increased by $2.3 \mathrm{~kg} / \mathrm{d}$ after their treatment with a combination of Enterocccus faceium, Lactobacillus plantarum, and Sacchormyces cerevisiae [17]. Moreover, mean daily yields of $4.0 \%$ fat corrected milk (FCM) were significantly increased by cows fed diet supplemented with $B$. licheniformis but not for Bacillus subtilis [16]. Also, cow's milk yield increased by $3.2 \mathrm{~kg} / \mathrm{d}$ with Bacillus subtilis natto supplementation [14]. In addition, goat's milk, 4\% FCM and the other components yields were higher with lactobacillus acidophilus supplementation [3]. However, somatic cell count (SCC) decreased beside increase milk yield has been observed for treated cows with mixture of Lactobacillus casei and Lactobacillus plantarum P-8 [19]. This suggested that such treatment can reduce mammary gland inflammation and subsequently increase animal's milk yield.

\section{Conclusion}

Lactic acid bacteria inclusion in dairy animals' diets lead to: A) improve feed efficiency with little change in dry matter intake. B) Increase ruminal total VFA concentrations especially propionate. C) Improve nutrients digestibility and, D) Increase milk yield with little effect on milk composition.

\section{Conflict of Interest}

The authors declare that there is no conflict of interest exists.

\section{References}

1. Azzaz HH, Mohamed El-Sherbiny HA, Murad, Ebeid HM (2019) Propionibacteria in Ruminant's diets: An overview. J Applied Sci 19: 166-172.

2. Azzaz HH, Morsy TA, Murad HA (2016) Microbial feed supplements for ruminant's performance enhancement. Asian J Agric Res 10: 1-14.

3. Azzaz HH, Hend A Aziz, Eman SA Farahat, Murad HA (2015) Impact of microbial feed supplements on the productive performance of lactating Nubian goats. Global Veterinaria 14(4): 567-575.

4. Chaucheyras-Durand F, Durand H (2010) Probiotics in animal nutrition and health. Benef Microb 1: 3-9.

5. Isolauri E, Sutas Y, Kankaanpaa P, Arvilommi H, Salminen S (2001) Probiotics: Effects on immunity. Am J Clin Nutr 73: 444-450.

6. Brandao RL, Castro IM, Bambirra EA, Amaral SC, Fietto LG, et al. (1998) Intracellular signal triggered by cholera toxin in Saccharomyces boulardii and Saccharomyces cerevisiae. Applied Environ Microbiol 64: 564-568.

7. Azzaz HH, Ebeid HM, Morsy TA, Kholif SM (2015) Impact of feeding yeast culture or yeast culture and propionibacteria169 on the productive performance of lactating buffaloes. International Journal of Dairy Science 10(3): 107-116.

8. Elam NA, Gleghorn JF, Rivera JD, Galyean ML, Defoor PI, et al. (2003) Effects of live cultures of Lactobacillus acidophilus (strains NP45 and NP51) and Propionibacterium freudenreichii on performance, carcass, and intestinal characteristics, and Escherichia coli strain 0157 shedding of finishing beef steers. J Anim Sci 81: 2686-2698.

9. Casewell M, Friis C, Marco E, McMullin P, Phillips I (2003) The European ban on growth-promoting antibiotics and emerging consequences for human and animal health. J Antimicrob Chemother 52: 159-161.

10. Krehbiel CR, Rust SR, Zhang G, Gilliland SE (2003) Bacterial directfed microbials in ruminant diets: Performance response and mode of action. Journal of Animal Science 81(14-2): E120-E132.] 
11. Gomez-Basauri J, de Ondarza MB, Siciliano-Jones l (2001) Intake and milk production of dairy cows fed lactic acid bacteria and mannanoligosaccharide. J Dairy Sci 84(1): 283.

12. Raeth-Knight ML, Linn JG, Jung HG (2007) Effect of Direct-Fed Microbials on Performance, Diet Digestibility, and Rumen Characteristics of Holstein Dairy Cows1. Journal of Dairy Science 90(4): 1802-1809.

13. Thompson KS (2011) Effect of site of infusion of lactobacillus acidophilus and propionibacterium freudenreichii on production and nutrient digestibility in lactating dairy cows. M.Sc. Thesis Oklahoma State University, Stillwater, Oklahoma p. 63.

14. Peng H, Wang JQ, Kang HY, Dong SH, Sun P, et al. (2012) Effect of feeding Bacillus subtilis natto fermentation product on milk production and composition, blood metabolites and rumen fermentation in early lactation dairy cows. Journal of animal physiology and animal nutrition 96(3): 506-512].

15. Sun P, Wang JQ, Deng LF (2013) Effects of Bacillus subtilis natto on milk production, rumen fermentation and ruminal microbiome of dairy cows. Animal 7(2): 216-222]

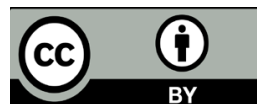

This work is licensed under Creative Commons Attribution 4.0 License

DOI: $10.19080 / J D V S .2019 .12 .555829$
16. Qiao GH, Shan AS, Ma N, Ma QQ Sun ZW (2008) Effect of supplemental Bacillus cultures on rumen fermentation and milk yield in Chinese Holstein cows. Journal of Animal Physiology and Animal Nutrition 94(4): 429-436.

17. Nocek JE, Kautz WP (2006) Direct-fed microbial supplementation on ruminal digestion, health, and performance of pre- and postpartum dairy cattle. J Dairy Sci 89: 260-266.

18. Luan S, Duersteler M, Galbraith EA, Cardoso FC (2015) Effects of direct-fed Bacillus pumilus 8G-134 on feed intake, milk yield, milk composition, feed conversion, and health condition of pre- and postpartum Holstein cows. J Dairy Sci 98: 6423-6432.

19. Haiyan Xu, Weiqiang Huang, Qiangchuan Hou, Lai-yu Kwok, Zhihong Sun, et al. (2017) The effects of probiotics administration on the milk production, milk components and fecal bacteria microbiota of dairy cows. Science Bulletin 62: 767-774.

\section{Your next submission with Juniper Publishers will reach you the below assets}

- Quality Editorial service

- Swift Peer Review

- Reprints availability

- E-prints Service

- Manuscript Podcast for convenient understanding

- Global attainment for your research

- Manuscript accessibility in different formats

(Pdf, E-pub, Full Text, Audio)

- Unceasing customer service

Track the below URL for one-step submission https://juniperpublishers.com/online-submission.php 